\title{
INVESTIGATING EXPERIENCED AND NOVICE ENGLISH LANGUAGE LEARNERS` PERCEPTIONS Of MOST USEFUL VOCABULARY LEARNING STRATEGIES (VLS)
}

Elnaz Zariholhosseini ${ }^{1}$, Ehsan Namaziandost ${ }^{2^{*}}$, Mehdi Nasri $^{3}$

${ }^{1}$ Department of Foreign Languages, Shahreza Branch, Islamic Azad University, Shahreza, Iran, ${ }^{2}$ Department of English, Faculty of Humanities, Shahrekord Branch, Islamic Azad University, Shahrekord, Iran, ${ }^{3}$ Department of English, Faculty of Humanities, Shahrekord Branch, Islamic Azad University, Shahrekord, Iran.

Email: ${ }^{1}$ Hossaini.elnaz@gmail.com, ${ }^{2 *}$ e.namazi75@yahoo.com, ${ }^{3}$ me_nasri@yahoo.com

Article History: Received on $29^{\text {th }}$ January 2020, Revised on $05^{\text {th }}$ March 2020, Published on $27^{\text {th }}$ March 2020

\section{Abstract}

Purpose of the study: This article report's findings from a study on the differences and similarities between experienced and novice English language learners with regards to their personal use of VLS.

Methodology: Closed questionnaire and semi-structure interviews were applied to collect the data. The questionnaire was distributed among 60 (30 experienced learners and 30 novice learners). In addition, 20 learners (10 experienced learners and 10 novice learners) were asked to answer the questions in the interview. Therefore, descriptive statistics, U Mann Whitney test, and independent-sample $t$-test were run to compare and analyzed the data.

Main Findings: The finding showed that there were significant differences between experienced and novice learners' thoughts towards vocabulary learning strategies and experienced learners used vocabulary learning strategies while learning new words in English language learning.

Applications of this study: If the learners are taught how to use each strategy correctly, their understanding of the language can naturally be improved. Moreover, VLS is beneficial throughout the process of vocabulary learning which makes learners more independent and allows teachers to focus on other things as well.

Novelty/Originality of this study: To the best of researchers' knowledge, no study has been done on investigating Iranian experienced and novice English language learners` perceptions towards most useful vocabulary learning strategies (VLS).

Keywords: Experienced Learners, Novice Learners, Learners`Perceptions, Vocabulary Learning, Vocabulary Teaching, Vocabulary Learning Strategies.

\section{INTRODUCTION}

It is commonly believed that vocabulary is regarded to be very crucial in all four English languages since it is one of the fundamental components needed for all stages of English education in second language learning (Gardner, 2013). Wilkins (1972, p.111) opinion about the importance of vocabulary in communication, "without grammar very little can be conveyed, without vocabulary, nothing can be conveyed" (Thornbury, 2002) is one of the most precious quotations of all time. Therefore, vocabulary is crucial in the acquisition of a second language. With regard to vocabulary acquisition, many scholars have long supported vocabulary learning strategies (VLS) to facilitate learning and to help improve the vocabulary knowledge of learners (Schmitt, 2000).

Vocabulary teaching has always played a significant role in Iranian EFL classrooms over several decades but obviously, VLS instruction seems to be barely applied in the classrooms of today. It is thus difficult for some Iranian EFL learners to acquire new words and this is likely because few VLS are familiar to them and they do not know how to utilize them appropriately. Typically, Iranian EFL learners prefer to use a bilingual dictionary as they may find that this is the best guide to use. Students should be provided with plenty of tactics, though, so they can determine for themselves when to use one technique instead of another. To be effective in language learning, learning techniques need to be part of what a learner has learned with respect to the target language. Strategies for language learning are purposeful acts the learners use to satisfy their learning needs. These strategies definitely help students develop self-regulation, excel in L2 activities and gain L2 skills (Oxford \&Amerstorfer, 2018). More critically, the techniques must be taught and learned in order to select the right tactics in various situations (Nisbet \&Shucksmith, 2017; Oxford \& Amerstorfer, 2018).

From another point of view, the most difficult part of learning a foreign language lies in mastering its vocabulary. Vocabulary is an unlimited set of items in comparison with grammar which is a system of limited rules. The use of vocabulary learning strategies is needed for learning vocabulary in the second language which is the focal attention of many researchers in second language acquisition.

The significance of the vocabulary has been perceived in pretty much every language-showing technique from the customary Silent Way in which the most adaptable and useful jargon was underlined (Richards \& Rodgers, 1999) to the later Communicate Language Teaching in which educators use a wide assortment of strategies, for example, definition, equivalent words, and antonyms, to instruct vocabulary (Savignon, 2002; Namaziandost, Shatalebi, \&Nasri, 2019). 
Successful communication, reading, and listening lead to vocabulary acquisition. Moreover, breakdowns in language production, reception, and communication are the result of unsuccessful vocabulary learning. In other words, overcoming vocabulary is notable for 12 learners since vocabulary ability can support them when they interact in the target language. It will be difficult for 12 learners if they lack vocabulary knowledge. Therefore, they may employ gestures, facial expressions, and body language to communicate and convey their intentions. English vocabulary skill is recognized as an essential skill for students in all the levels of proficiency (Namaziandost, Neisi, Kheryadi, \& Nasri, 2019).

Vocabulary acquisition also remains a very active area of research with significant implications to inform practice (Adolphs \& Schmitt, 2004), what's more, it is expected that development in jargon happens because of increases in language capability. Without jargon, the abilities of language getting the hang of including perusing, composing, talking and listening may not be effectively accomplished (Zhiliang, 2008; Namaziandost, \& Çakmak, 2020).

Sufficient vocabulary knowledge is required for all the learners in order to perform well at listening, speaking, reading, and writing. For example, the repertory of vocabulary items is necessitated when the learners are asked to have a piece of meaningful and comprehensive writing. Vocabulary learning is one of the most complex processes that foreign language learners face while experiencing a new language. Further, it is a more intricate procedure than remembering the implications of words since it envelopes seeing, hearing and utilizing words in significant settings.

This article reports findings from a study on the differences and similarities between experienced and novice English language learners with regards to their personal use of VLS.

\section{LITERATURE REVIEW}

Mastering vocabulary was not fully deserved for decades because of overpowering stress on mastering syntax, but these days, literature and research on vocabulary learning and teaching are immense. In this part, the definition of vocabulary learning strategy is provided followed by some researches related to different perceptions of language learners about vocabulary learning strategies (VLS).

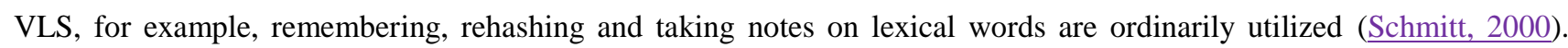
Schmitt sees that novices use 'shallow' techniques for jargon learning, for example, retention and reiteration, and propelled students to use 'deeper' procedures, for example, union and assurance systems (p. 132).

Suberviola and Méndez (2002) examined the need, strategies, and exercises of jargon obtaining, stressing the significance of semantic maps in upgrading learners' capacity to review words. Qian (2004) researched lexical surmising methodologies among Korean and Chinese learners of English to locate that a top-down methodology, explicitly speculating from the setting, was the significant system utilized. In an experimental study, Zhiliang (2008) inspected the impact of three learning methodologies on Chinese EFL students' accidental jargon learning. The examination created proof for the prevalence of the joined strategy for speculating and an e-lexicon over speculating from setting utilizing an e-word reference.

Hurtado (2002) led an investigation on the most proficient method to show jargon, recommending that 'lexical pecking orders' are an appropriate method for introducing words methodically since 'One of the Catch 22s in VT in the FL study hall is that notwithstanding the measure of time dedicated to clarifying and characterizing words, jargon is once in a while introduced to learners in an efficient way' (p. 176).

The inquiry about whether students will utilize VLS relies upon various factors, for example, inspiration, capability, and culture (Schmitt, 2000). For instance, culture can influence their inclination for specific learning procedures ( $\underline{\text { Schmitt, }}$ 2000). In Hong Kong, most students are utilized to repetition learning and would not have the option to become accustomed to another system (Schmitt, 2000). Another significant factor is to persuade the learners of the requirement for methodology preparing, as a past report has indicated that students who had not experienced procedure preparation had performed more terrible than students who utilized their own repetition learning systems (Schmitt, 2000). Proficiency is additionally significant in light of the fact that amateur students may be confined to the utilization of word records, while propelled students may figure the importance of words from the content (Schmitt, 2000).

Schmitt (2000) gathered a rundown of VLS classified by the accompanying two purposes:

1) Techniques that find another word's significance; and 2) systems that merge a word once it has been experienced.

Below is a list of VLS from Schmitt's (2002) taxonomy, which incorporates a wide range of techniques, exceedingly significant aptitudes in the student's procedure.

Assurance systems are singular learning techniques, which help students to find the significance of words without anyone else with no help from peers, for example, speculating the words from the specific circumstance (Schmitt, 2000).

Social strategies connect with students in collaboration with their companions, and this encourages them to gain from one another, for example, watching their colleagues and approaching their educator for the significance of a word (Namaziandost, Fatahi, \& Shafiee 2019). 
Memory strategies are methodologies, which draw in students in learning the new word through mental handling by partner their current or foundation information with the new word (Namaziandost, Fatahi, \& Shafiee 2019).

Cognitive strategies do not connect with students in mental preparing however is progressively mechanical. A model is rehashing the way to express new words (Schmitt, 2000).

Metacognitive strategies are systems identifying with forms including observing, dynamic, and assessment of one's advancement. Metacognitive procedures help the student in deciding fitting VLS for learning new words (Namaziandost, Fatahi, \& Shafiee, 2019).

This study aims to investigate experienced and novice English language learners` perceptions and attitudes towards different vocabulary learning strategies when they experience English language learning.

To achieve this aim, the following research questions are addressed:

1. What is the most frequently used vocabulary language learning strategy by experienced and novice English language learners?

2. What is the most useful vocabulary language learning strategy by experienced and novice teachers?

3. What are the differences and similarities between experienced and novice English language learners ` perceptions of VLS?

\section{METHODOLOGY}

This section introduced the participants, research instruments and data analysis methods used in the research.

\section{Design and Context of the Study}

It is a descriptive study. Differences and similarities between experienced and novice English language learners perceptions towards vocabulary learning strategy are described. The qualitative method was employed to investigate the research questions in this study. Quantitative strategies can uncover, for instance, potential issues in executing a proposed trial of elective single undeveloped organism's move, where little gathering conversations empower staff to clarify their opposition, prompting a revised methodology (Porter \& Bhattacharya, 2005).

\section{Participants}

The participants of the study are 40 learners (20 advanced learners and 20 beginner learners) learning English as a foreign language in some branches of the Gooyesh Language Institute. These learners' study Top Notch Series Books and they are selected as experienced and novice according to the level of the book that they are studying. Experienced learners' study Top Notch Level 4 and novice learners study Top Notch Level 1.

Table 1: The demographic background of the participants

\begin{tabular}{ll}
\hline No. of Learners & $60(30$ Experienced learners and 30 Novice learners $)$ \\
\hline Gender & Female \\
\hline Native Language & Persian \\
\hline Academic Year & $2019-2020$ \\
\hline
\end{tabular}

\section{Instruments}

One questionnaire accompanied by an interview was designed to elicit the English language learners `perception of the most frequent and most useful vocabulary learning strategy. In the first place, the data required for this study are collected using a questionnaire, adopted and adapted from Takač (2008). The participants were required to select each statement on a three-point Likert scale (i.e., 1: Never, 2: Sometimes, and 3: Always). Cronbach Alpha reliability coefficient was used to assess the reliability of the questionnaire. The reliability found as 0.787 which showed acceptable reliability.

Interviewers are useful to obtain detailed information about personal feelings, perceptions and opinions and they lead to deepening understanding of individuals. The interviewee consisted of 20 learners (10 experienced learners and 10 novice learners) and they were interviewed to gain a deep understanding of their perception toward vocabulary learning strategy.

\section{Data Collection Procedure}

The questionnaire is distributed in some branches of the Gooyesh Language Institute to answer the research questions and the researcher conducts the study by the permission of the managers in each branch. The participants are aware of the research purposes and they are certain that their information would be kept anonymous.

\section{Data analysis Procedure}

The method of analysis was statistical analysis. Therefore, the research questions were analyzed with the help of statistical software package SPSS, version 26 to elicit meaningful conclusions. The data gathered from the instruments were analyzed descriptively and inferential by applying frequency, percentage, mean, standard deviation, U Mann Whitney test, and independent-sample $t$-test. They were used to compare the perceptions of these two groups of teachers 
and to describe the similarities and differences. Qualitative data gathered through interviews were transcribed and included in the study for more clarification of the data.

\section{RESULT}

To investigate what experienced and novice EFL learners though about vocabulary learning strategies in learning a foreign language, 26 questions were asked to both experienced and novice learners. The results gained are presented in Table 2 below.

Table 2: Perceptions of Experienced Learners toward Vocabulary Learning Strategies

\begin{tabular}{ccccccccc}
\hline & \multicolumn{2}{c}{ Never } & \multicolumn{2}{c}{ Sometimes } & \multicolumn{2}{c}{ Always } & \multirow{2}{*}{ Mean } & \multirow{2}{*}{ St. D } \\
\cline { 2 - 6 } Items & $\mathrm{F}$ & $\mathrm{P}$ & $\mathrm{F}$ & $\mathrm{P}$ & $\mathrm{F}$ & $\mathrm{P}$ & & 2.63 \\
\hline Question 1 & 1 & 3.3 & 9 & 30.0 & 20 & 66.7 & .56 \\
\hline Question 2 & 27 & 90.0 & 3 & 10.0 & 0 & 0.0 & 1.10 & .31 \\
\hline Question 3 & 0 & 0.0 & 14 & 46.7 & 16 & 53.3 & 2.53 & .51 \\
\hline Question 4 & 0 & 0.0 & 16 & 53.3 & 14 & 46.7 & 2.47 & .51 \\
\hline Question 5 & 2 & 6.7 & 8 & 26.7 & 20 & 66.7 & 2.60 & .62 \\
\hline Question 6 & 0 & 0.0 & 3 & 10.0 & 27 & 90.0 & 2.90 & .31 \\
\hline Question 7 & 6 & 20.0 & 20 & 66.7 & 4 & 13.3 & 1.93 & .58 \\
\hline Question 8 & 7 & 23.3 & 7 & 23.3 & 16 & 53.3 & 2.30 & .84 \\
\hline Question 9 & 2 & 6.7 & 4 & 13.3 & 24 & 80.0 & 2.73 & .58 \\
\hline Question 10 & 18 & 60.0 & 10 & 33.3 & 2 & 6.7 & 1.47 & .63 \\
\hline Question 11 & 12 & 40.0 & 4 & 13.3 & 14 & 46.7 & 2.07 & .94 \\
\hline Question 12 & 1 & 3.3 & 6 & 20.0 & 23 & 76.7 & 2.73 & .52 \\
\hline Question 13 & 2 & 6.7 & 8 & 26.7 & 20 & 66.7 & 2.60 & .62 \\
\hline Question 14 & 26 & 86.7 & 2 & 6.7 & 2 & 6.7 & 1.20 & .55 \\
\hline Question 15 & 1 & 3.3 & 8 & 26.7 & 21 & 70.0 & 2.67 & .55 \\
\hline Question 16 & 3 & 10.0 & 13 & 43.3 & 14 & 46.7 & 2.37 & .67 \\
\hline Question 17 & 0 & 0.0 & 14 & 46.7 & 16 & 53.3 & 2.53 & .51 \\
\hline Question 18 & 1 & 3.3 & 21 & 70.0 & 8 & 26.7 & 2.23 & .50 \\
\hline Question 19 & 25 & 83.3 & 4 & 13.3 & 1 & 3.3 & 1.20 & .48 \\
\hline Question 20 & 2 & 6.7 & 15 & 50.0 & 13 & 43.3 & 2.37 & .61 \\
\hline Question 21 & 4 & 13.3 & 11 & 36.7 & 15 & 50.0 & 2.37 & .72 \\
\hline Question 22 & 0 & 0.0 & 10 & 33.3 & 20 & 66.7 & 2.67 & .48 \\
\hline Question 23 & 0 & 0.0 & 2 & 6.7 & 28 & 93.3 & 2.93 & .25 \\
\hline Question 24 & 6 & 20.0 & 11 & 36.7 & 13 & 43.3 & 2.23 & .77 \\
\hline Question 25 & 24 & 80.0 & 4 & 13.3 & 2 & 6.7 & 1.27 & .58 \\
\hline Question 26 & 1 & 3.3 & 3 & 10.0 & 26 & 86.7 & 2.83 & .46 \\
\hline & & & & & & & &
\end{tabular}

Source: SPSS, Version 26

As can be seen in table 2, the highest mean among the experienced learners is related to questions 23,6 , and 26 which are $2.93,2.90$, and 2.83 , respectively. The mean of question 23 is equal to $2.93 \pm .25$ and two of the experienced learners (6.7\%) agree with sometimes and 28 of them (98.3\%) agree with always. The mean of question 6 is equal to $2.90 \pm .31$ and three of them (10\%) agreed with sometimes and 27 of them (90\%) agreed with always. The mean of question 26 is $2.83 \pm .46$ and just one of them (3.3\%) agreed with never, 3 of them (10\%) agreed with sometimes, and 26 of them (86.7\%) agreed with always.

In contrast, the lowest mean among experienced learners is related to questions 2,19 , and 14 . The mean of question 2 is $1.10 \pm .31$ and 27 of them (90\%) agreed with never and 3 of them (10\%) agreed with sometimes. The mean of question 19 is $1.20 \pm .48$ and 25 of them (83.3\%) marked never, 4 of them (13.3\%) agreed with sometimes, and only one of them (3.3\%) agreed with always. The mean of question 14 is equal to $1.20 \pm .55$ and 26 of them (86.7\%) answered never, 2 of them $(6.7 \%)$ marked sometimes, and 2 of them (6.7\%) agreed with always.

Table 3: Perceptions of Novice Learners Toward Vocabulary Learning Strategies

\begin{tabular}{ccccccccc}
\hline \multirow{2}{*}{ Items } & \multicolumn{2}{c}{ Disagree } & \multicolumn{2}{c}{ Undecided } & \multicolumn{2}{c}{ Agree } & \multirow{2}{*}{ Mean } & \multirow{2}{*}{ St. D } \\
\cline { 2 - 7 } & $\mathrm{F}$ & $\mathrm{P}$ & $\mathrm{F}$ & $\mathrm{P}$ & $\mathrm{F}$ & $\mathrm{P}$ & & .63 \\
\hline Question 1 & 2 & 6.7 & 9 & 30.0 & 19 & 63.3 & 2.57 & .63 \\
\hline Question 2 & 2 & 6.7 & 12 & 40.0 & 16 & 53.3 & 2.47 & .50 \\
\hline Question 3 & 0 & 0.0 & 13 & 43.3 & 17 & 56.7 & 2.57 & .51 \\
\hline Question 4 & 0 & 0.0 & 14 & 46.7 & 16 & 53.3 & 2.53 & .61 \\
\hline Question 5 & 12 & 40.0 & 16 & 53.3 & 2 & 6.7 & 1.67 & \\
\hline
\end{tabular}




\begin{tabular}{ccccccccc}
\hline Question 6 & 21 & 70.0 & 8 & 26.7 & 1 & 3.3 & 1.33 & .55 \\
\hline Question 7 & 20 & 66.7 & 8 & 26.7 & 2 & 6.7 & 1.40 & .62 \\
\hline Question 8 & 13 & 43.3 & 12 & 40.0 & 5 & 16.7 & 1.73 & .74 \\
\hline Question 9 & 11 & 36.7 & 10 & 33.3 & 9 & 30.0 & 1.93 & .83 \\
\hline Question 10 & 1 & 3.3 & 5 & 16.7 & 24 & 80.0 & 2.77 & .50 \\
\hline Question 11 & 14 & 46.7 & 9 & 30.0 & 7 & 23.3 & 1.77 & .82 \\
\hline Question 12 & 4 & 13.3 & 5 & 16.7 & 21 & 70.0 & 2.57 & .73 \\
\hline Question 13 & 22 & 73.3 & 6 & 20.0 & 2 & 6.7 & 1.33 & .61 \\
\hline Question 14 & 3 & 10.0 & 12 & 40.0 & 15 & 50.0 & 2.40 & .67 \\
\hline Question 15 & 16 & 53.3 & 12 & 40.0 & 2 & 6.7 & 1.53 & .63 \\
\hline Question 16 & 2 & 6.7 & 13 & 43.3 & 15 & 50.0 & 2.43 & .63 \\
\hline Question 17 & 18 & 60.0 & 10 & 33.3 & 2 & 6.7 & 1.47 & .63 \\
\hline Question 18 & 3 & 10.0 & 20 & 66.7 & 7 & 23.3 & 2.13 & .57 \\
\hline Question 19 & 2 & 6.7 & 7 & 23.3 & 21 & 70.0 & 2.63 & .61 \\
\hline Question 20 & 2 & 6.7 & 16 & 53.3 & 12 & 40.0 & 2.33 & .61 \\
\hline Question 21 & 5 & 16.7 & 11 & 36.7 & 14 & 46.7 & 2.30 & .75 \\
\hline Question 22 & 13 & 43.3 & 14 & 46.7 & 3 & 10.0 & 1.67 & .66 \\
\hline Question 23 & 22 & 73.3 & 6 & 20.0 & 2 & 6.7 & 1.33 & .61 \\
\hline Question 24 & 3 & 10.0 & 11 & 36.7 & 16 & 53.3 & 2.43 & .68 \\
\hline Question 25 & 1 & 3.3 & 6 & 20.0 & 23 & 76.7 & 2.73 & .52 \\
\hline Question 26 & 2 & 6.7 & 4 & 13.3 & 24 & 80.0 & 2.73 & .58 \\
\hline
\end{tabular}

Source: SPSS, Version 26

According to table 3 , the highest mean among novice learners is related to questions 10,25 , and 26, respectively. The mean of question 10 is equal to $2.77 \pm .50$ and only one of the novice learners (3.3\%) agreed with never, 5 of them (16.7\%) marked sometimes, and 24 of them (80\%) answered always. The mean of question 25 is $2.73 \pm .52$ and just one of them (3.3\%) agreed with never, 6 of them (20\%) agreed with sometimes, and 23 of them (76.7\%) agreed with always. The mean of question 26 is $2.73 \pm .58$ and 2 of them (6.7\%) agreed with never, 4 of them (13.3\%) agreed with sometimes, and 24 of them (80\%) answered always.

The lowest mean is related to questions 6,13 , and 23. The mean of question 6 is equal to $1.33 \pm .55$ and 21 of them (70\%) agreed with never, 8 of them (26.7\%) agreed with sometimes, and always option was true with only one of the learners. The mean of question 13 is equal to $1.33 \pm .61$ and 22 of them (73.3\%) agreed with never, 6 of them (20\%) agreed with sometimes, and 2 of them (6.7\%) agreed with always. The mean of question 23 is $1.33 \pm .61$ which is the same as the mean of question 13.22 of them (73.3\%) believed in never, and 6 of them (20\%) agreed with sometimes, and 2 of them (6.7\%) answered always.

Table 4: Comparing Experienced and Novice Learners' Perceptions of Vocabulary Learning strategies

\begin{tabular}{cccccc}
\hline & \multicolumn{2}{c}{ Experience } & \multicolumn{2}{c}{ Novice } & \multirow{2}{*}{ Sig. } \\
\cline { 2 - 5 } Items & Mean & Std & Mean & Std & \\
\hline Question 1 & 2.63 & .56 & 2.57 & .63 & 0.730 \\
\hline Question 2 & 1.10 & .31 & 2.47 & .63 & $<0.001$ \\
\hline Question 3 & 2.53 & .51 & 2.57 & .50 & 0.797 \\
\hline Question 4 & 2.47 & .51 & 2.53 & .51 & 0.609 \\
\hline Question 5 & 2.60 & .62 & 1.67 & .61 & $<0.001$ \\
\hline Question 6 & 2.90 & .31 & 1.33 & .55 & $<0.001$ \\
\hline Question 7 & 1.93 & .58 & 1.40 & .62 & 0.001 \\
\hline Question 8 & 2.30 & .84 & 1.73 & .74 & 0.008 \\
\hline Question 9 & 2.73 & .58 & 1.93 & .83 & $<0.001$ \\
\hline Question 10 & 1.47 & .63 & 2.77 & .50 & $<0.001$ \\
\hline Question 11 & 2.07 & .94 & 1.77 & .82 & 0.209 \\
\hline Question 12 & 2.73 & .52 & 2.57 & .73 & 0.451 \\
\hline Question 13 & 2.60 & .62 & 1.33 & .61 & $<0.001$ \\
\hline Question 14 & 1.20 & .55 & 2.40 & .67 & $<0.001$ \\
\hline Question 15 & 2.67 & .55 & 1.53 & .63 & $<0.001$ \\
\hline Question 16 & 2.37 & .67 & 2.43 & .63 & 0.723 \\
\hline Question 17 & 2.53 & .51 & 1.47 & .63 & $<0.001$ \\
\hline Question 18 & 2.23 & .50 & 2.13 & .57 & 0.508 \\
\hline Question 19 & 1.20 & .48 & 2.63 & .61 & $<0.001$ \\
\hline
\end{tabular}




\begin{tabular}{|c|c|c|c|c|c|}
\hline Question 20 & 2.37 & .61 & 2.33 & .61 & 0.816 \\
\hline Question 21 & 2.37 & .72 & 2.30 & .75 & 0.740 \\
\hline Question 22 & 2.67 & .48 & 1.67 & .66 & $<0.001$ \\
\hline Question 23 & 2.93 & .25 & 1.33 & .61 & $<0.001$ \\
\hline Question 24 & 2.23 & .77 & 2.43 & .68 & 0.320 \\
\hline Question 25 & 1.27 & .58 & 2.73 & .52 & $<0.001$ \\
\hline Question 26 & 2.83 & .46 & 2.73 & .58 & 0.479 \\
\hline
\end{tabular}

Source: SPSS, Version 26

According to table 4, the U Mann Whitney Test was applied to investigate the similarities and differences between these two groups of learners. As it can be seen, there were significant differences between these two groups of learners concerning strategies $2,5,6,7,8,9,10,13,14,15,16,17,19,22,23$, and $25(\mathrm{p}<0.05)$. Moreover, experienced learners used vocabulary learning strategies $5,6,7,8,9,13,15,17,22$, and 23 more than novice learners. In contrast, novice learners applied vocabulary learning strategies $2,10,14,19$, and 25 more in comparison with experienced learners.

Table 5: Comparing Experienced vs. Novice Learners' Perceptions of Vocabulary Learning strategies

\begin{tabular}{ccccccc}
\hline Group & \multicolumn{3}{c}{ Descriptive Statistics } & \multicolumn{2}{c}{ Results of T-test } \\
\cline { 2 - 6 } & $\mathbf{N}$ & Mean & Std. Deviation & T & df & Sig. \\
\hline experience & 30 & 58.93 & 2.52 & \multirow{2}{*}{5.206} & \multirow{2}{*}{58} & $<.001$ \\
\hline novice & 30 & 54.77 & 3.59 & &
\end{tabular}

Source: SPSS, Version 26

According to Table 5, there was a significant difference $(\mathrm{t}(58)=5.206, \mathrm{p}<.001)$ between the mean of these two groups of learners based on an independent sample $t$-test. It suggested that the mean of experienced learners $(\mathrm{M}=58.93, \mathrm{SD}=2.52)$ was higher than the mean of novice teachers $(M=54.77, \mathrm{SD}=3.59)$. Therefore, vocabulary learning strategies (VLSs) were more useful for experienced learners than novice learners while learning new words in English.

\section{DISCUSSION AND CONCLUSION}

The present study aimed to investigate the perceptions of experienced and novice EFL learners in terms of using vocabulary learning strategies in English language classrooms. Therefore, the results of both groups of the teachers might be valuable for the field of foreign language learning and to provide English learners with effective vocabulary learning strategies in the face of difficulties.

The inclination of the learners right now favor the utilization of intellectual techniques for rehashing the words in their psyche might be clarified by the social impact of Confucianism which esteems exertion and diligence ( $\underline{\mathrm{Wu}, 2008)}$.

The survey aftereffects of this investigation correspond with those of earlier examinations on VLS in Hong Kong and different pieces of Asia. For instance, the discoveries from this investigation about learners preferring the system of spelling words in their psyches were like that from Lo 's (2007) study. It was fascinating to take note of that the two examinations utilized a similar survey adjusted from Cheung (2004), but learners in Lo's examination were Chinese EFL auxiliary learners while the learners right now Iranian EFL learners.

The study arrived at the result that the effective learning of vocabulary among experienced and novice EFL Iranian students were significantly related to their perceptions about the usefulness of the VLS. It showed that learners who often use a VLS would regard it as a very useful strategy to apply for learning new words. The learner would find out the usefulness of VLS when they use them more and more.

Moreover, the findings yielded that experienced learners were more aware of vocabulary learning strategies than novice learners. They were more able to employ a wide range of strategies and techniques, solve problems in case of difficulty, and provide a relaxing environment for learning. At the same time, novice learners were eager to use VLSs but they had low awareness in using the strategies because of low years of learning experiences.

The answers provided with the learners largely suggested that more training and practicing was necessary about how to use VLSs and how to learn new words effectively. Applying these strategies was limited and personal to the individuals and it needed training and nurturing to be developed. The present study drew the understanding of effective VLSI.

It can yield numerous advantages if the learners are told accurately and effectively on how and when to utilize this sort of word reference. Yet, now, regardless of which methodology, it is increasingly critical to take a gander at the adequacy of VLS guidance. In the event that the learners are instructed how to suitably utilize every procedure, their jargon information will clearly be upgraded. Namaziandost, Fatahi, and Shafiee (2019) focused on that VLS is helpful all through the vocabulary learning process which makes students progressively free and allows instructors to also center around different things. He likewise exhorted that technique preparing is incorporated in a course with this proposed arrangement: instructors ought to choose which systems must be stressed, realize how to oversee time astutely while preparing students, offer open doors for students to practice the procedures and give input on their methodology use. 
Oxford (2002) likewise demands that it is important that instructors expand the learners' information on the techniques too. Accordingly, it is both the instructors' and the students' obligation to partake in the learning process so the learners will have the option to autonomously utilize VLS in their continuous vocabulary learning. Therefore, it must start with the educators who need to rouse their learners to recognize the significance of VLS and furnish them with thoughts on the best way to utilize them.

The results of this study are in line with Namaziandost, Fatahi, and Shafiee (2019) who confirmed that selecting an appropriate strategy of vocabulary learning for language learners pave the way for enhancing lexical knowledge for them.

Oxford (2002) referenced numerous ways instructors can energize powerful technique use: looking at students' utilization of methodologies through system reviews, perceptions or conversations with students and seeing the adequacy of the procedures utilized, furnishing students with a wide assortment of strategies, demonstrating how to utilize strategies for a specific errand (for example beginning with metacognitive strategies followed by psychological strategies with social strategies), consolidating technique preparing into ordinary teaching method rather than in discrete courses, and soliciting students to assess their methodologies use. From Oxford's perspective, it doesn't really should be a different course of VLS guidance, it very well may be coordinated into any English course to encourage students as long as the educators realize how to proficiently pass on the guidelines.

As far as pedagogical consequences are concerned, English-language lecturers will devise activities for learners to improve their ability to use vocabulary strategies for both monolingual and bilingual learners It is important to teach learners to use vocabulary strategies effectively because not everyone is familiar with the use of these strategies. As proposed by Wolter (2015), EFL teachers must pay attention to their learners ' skills and desires around strategy use, to ensure they have the potential to use strategies effectively. Teachers also need to learn what strategies students like to learn, what details they find important and see if they use all the available strategies.

\section{LIMITATIONS AND STUDY FORWARD}

Like many other studies in the field of foreign language teaching and learning, there were some limitations in this study. This study was carried out in only one of the language institutes in Isfahan, Iran. Therefore, the findings were not generalizable. Another one had to do with the sample size. Definitely, a large sample would generate more reliable results. In addition, the age and gender of the learners were two important biological variables that could play significant roles in practicing vocabulary learning strategies (VLSs) in learning new words.

\section{AUTHORS CONTRIBUTION}

All authors of the research had more or less equal contributions in the process of conception and design, acquisition of data, and analysis and interpretation of data. They have all been involved in revising the manuscript critically to the same extent. All take public responsibility for the whole content. All are equally accountable for all aspects of the work. All authors read and approved the final manuscript.

\section{REFERENCES}

1. Adolphs, S., \& Schmitt, N. (2004). Vocabulary coverage according to spoken discourse context. In P. Bogaards\& B. Laufer (Eds.), vocabulary in a second language (pp. 349). Amsterdam: John Benjamins Publishing Company. https://doi.org/10.1075/11lt.10.05ado

2. Cheung, C.Y. (2004). The effectiveness of vocabulary learning strategies of Chinese low achievers. Unpublished master's thesis. The University of Hong Kong, Hong Kong.

3. Gardner, D. (2013). Exploring vocabulary: Language in action. London, England: Routledge. https://doi.org/10.4324/9780203798683

4. Hurtado, C.J. (2002). Lexical hierarchies as a strategy of teaching vocabulary. In W. Gewehr (ED), Aspects of modern language teaching in Europe (pp. 176-189). New York, NY: Routledge.

5. Lo, O.K. (2007). An investigation into the perceptions and effectiveness of various vocabulary learning strategies of Hong Kong ESL learners with low English proficiency. Unpublished master's thesis, The University of Hong Kong, Hong Kong.

6. Namaziandost, E., \&Çakmak, F. (2020). An account of EFL learners' self-efficacy and gender in the Flipped Classroom Model. Education and Information Technologies, 25(2). https://doi.org/10.1007/s10639-020-10167-7

7. Namaziandost, E., Fatahi, M., \&Shafiee, S. (2019).The relationship between Iranian upper-intermediate EFL learners' contrastive lexical competence and their use of vocabulary learning strategies. International Journal of Foreign Language Teaching \& Research - 7(28),105-120.

8. Namaziandost, E., Neisi, L., Kheryadi, \&Nasri, M. (2019). Enhancing oral proficiency through cooperative learning among intermediate EFL learners: English learning motivation in focus. Cogent Education, 6(1),1-15. https://doi.org/10.1080/2331186X.2019.1683933

9. Namaziandost, E., Shatalebi, V., \&Nasri, M. (2019). The impact of cooperative learning on developing speaking ability and motivation toward learning English. Journal of Language and Education, 5(3), 83-101. https://doi.org/10.17323/jle.2019.9809 
10. Nisbet, J., \&Shucksmith, J. (2017). Learning strategies. London, England: Routledge. https://doi.org/10.4324/9781315188652

11. O’Malley, J. M. and Chamot, A.U. (1990). Learning strategies in second language acquisition. Cambridge: Cambridge University Press. https://doi.org/10.1017/CBO9781139524490

12. Oxford, R. L. (2002). Language learning strategies: What every teacher should know. New York, NY:Newbury House.

13. Oxford, R. L., \&Amerstorfer, C. M. (Eds.). (2018). Language learning strategies and individual learnercharacteristics: Situating strategy use in diverse contexts. London, England: Bloomsbury.

14. Porter M, Bhattacharya S. Investigation of staff and patients' opinions of a proposed trial of elective single embryo transfer. Hum Reprod 2005; 20: 2523-2530. https://doi.org/10.1093/humrep/dei094

15. Qian, D. D. (2004). Second language lexical inferencing: Preferences, perceptions, and practices. In P. Bogaards\& B. Laufer (Eds.), vocabulary in a second language (pp. 155-169). Amsterdam: John Benjamins Publishing Company. https://doi.org/10.1075/11lt.10.11qia

16. Richards, J. C., \& Rodgers, T. C. (1999). Approaches and methods in language teaching, Cambridge, UK: Cambridge University Press.

17. Sauvignon, S. J. (2002). Communicative language teaching: Linguistic theory and classroom practice. In S. J. Savignon (Ed.), Interpreting communicative language teaching: contexts and concerns in teacher education (pp. 1-28). London, UK: Yale University Press.

18. Schmitt, N. (2000). Vocabulary in language teaching. Cambridge University Press, Cambridge.

19. Suberviola, E. S., \& Méndez, R. V. (2002). Vocabulary acquisition strategies. Didáctica (LenguayLiteratura), 14, 233-250.

20. Takač, V. P. (2008). Vocabulary learning strategies and foreign language acquisition. Clevedon, UK: Multilingual Matters Ltd. https://doi.org/10.21832/9781847690401

21. Thornbury, S. (2002). How to teach vocabulary. Harlow, England: Longman.

22. Wilkins, D. A. (1972). Linguistics in Language Teaching. London, England: Arnold.

23. Wolter, L. A. (2015). Dictionary use and preferences of L2 English learners in an intensive Englishcontext. Culminating Projects in English.

24. Wu, M.M.F. (2008). Language learning strategy use of Chinese ESL learners of Hong Kong-findings from a qualitative study. Electronic Journal of Foreign Language Teaching, 5(1), 68-83.

25. Zhiliang, S. (2008). A comparative study of three learning strategies in EFL students' incidental vocabulary acquisition. CELEA Journal, 31(6), 92-101. 